\title{
The effect of elevated ambient temperature on spermatogenesis in the boar
}

\author{
R. D. A. Cameron and A. W. Blackshaw* \\ Departments of Veterinary Medicine and ${ }^{*}$ Physiology, University of Queensland, \\ St. Lucia 4067, Queensland, Australia
}

\begin{abstract}
Summary. Boars were heated for $6 \mathrm{~h} /$ day in a climate chamber (mean maximum temperatures, $33.4 \pm 3 \cdot 1-37.7 \pm 2 \cdot 0^{\circ} \mathrm{C}$, and relative humidities $40-80 \%$ ) for 4,5 and 7 days respectively ( 4 boars/group). Significant increases in the proportion of morphologically abnormal spermatozoa were seen in all groups for the end of Week 2 and up to Week 5 after treatment. Boars exposed for 7 days were, in general, more severely affected.

Ejaculate volumes, gel volumes, sperm concentration and daily sperm outputs were not affected significantly in any of the groups, although changes were seen in individual animals. In some boars heat stress early in the treatment period produced an acute rise in body temperature which appeared to have a greater effect on semen quality than did the duration of exposure.
\end{abstract}

\section{Introduction}

The effect of elevated ambient temperature on semen quality has been studied extensively in most of the farm animal species. In the ram, studies by McKenzie \& Berliner (1937), Gunn, Sanders \& Granger (1942), Dutt \& Hamm (1957), and Cameron (1971) have shown a decline in semen quality during hot summer periods. Similar findings have been reported for the bull (Phillips, Knapp, Heemstra \& Eaton, 1945; Anderson, 1945). Adverse changes in semen quality have been produced in the ram (Braden \& Mattner, 1970; Samisoni \& Blackshaw, 1971) and in the bull (Singleton, 1974), by heating animals or by applying local heat to the testis. A decrease in reproductive performance in boars during and immediately after hot summer weather has been reported (Thibault et al., 1966; Signoret \& du Mesnil du Buisson, 1968; Lawrence, Turman, Rich, Sharp \& Hillies, 1970; Stork, 1979). Mazzarri, du Mesnil du Buisson \& Ortavant (1968) raised testicular temperature in the boar to approximately $40^{\circ} \mathrm{C}$ for $3 \mathrm{~h}$ and produced a marked decrease in sperm concentration and motility 2-8 weeks later. Continuous heat stress over $72 \mathrm{~h}$ resulted in a decrease of semen quality and fertility 3-5 weeks later (McNitt \& First, 1970; Christenson, Teague, Grifo \& Roller, 1972). When Wettemann, Wells, Omtvedt, Pope \& Turman (1976) exposed boars to elevated ambient temperature daily for 90 days they found a reduced sperm output and an increase in the number of abnormal spermatozoa during the 2 nd week of treatment.

The present study was designed to determine the effect on spermatogenesis and daily sperm output of exposure of boars to relatively short periods of elevated ambient temperatures, with diurnal variations similar to those experienced in many of the pig-producing areas of sub-tropical Australia. 


\section{Materials and Methods}

Boars. The 12 boars (Large White $\times$ Landrace, 12-15 months of age) were trained to mount a dummy sow for semen collection by the gloved-hand method. The boars were kept in individual pens and fed $2 \mathrm{~kg}$ dry pelleted ration daily. Temperatures in the boar house ranged from a minimum of $18^{\circ} \mathrm{C}$ to a maximum of $30^{\circ} \mathrm{C}$ throughout the experimental period. Rectal temperatures recorded in these boars were $37.5-38.5^{\circ} \mathrm{C}$ and scrotal temperatures were $32-33 \cdot 5^{\circ} \mathrm{C}$.

Semen collection and evaluation. To stabilize epididymal sperm reserves, semen was collected from each boar 3 times weekly on Mondays, Wednesdays and Fridays for 6 weeks before the heat treatment. Semen collections continued at the same frequency during and for 8 weeks following the treatment period.

A prewarmed $\left(38^{\circ} \mathrm{C}\right)$ 1-litre, insulated polyethylene container was used to collect the semen. Immediately ejaculation was completed sperm motility was examined using a light microscope with a warm-stage attachment, and the percentage of motile spermatozoa was estimated by visual appraisal. The ejaculate volume was measured, the gel fraction filtered off using surgical gauze, and the volume of gel calculated.

Sperm concentration and total sperm number were determined using a haemocytometer. Daily sperm output was calculated from the ejaculates collected during the last 2 weeks of the 6-week pretreatment period by dividing the total number of spermatozoa by the number of 24-h intervals, after the technique of Kennelly \& Foote (1964).

Morphology of the head, midpiece and tail of spermatozoa was studied, using formol saline preparations examined by oil-immersion phase-contrast microscopy and freshly prepared smears stained with carbol fuchsin and eosin and counterstained with Loeffler's methylene blue (Williams' stain) as described by Lagerlöf (1936).

Heat treatment. The 12 boars were divided into 3 equal groups. All the boars were subjected to temperatures of $35-40^{\circ} \mathrm{C}$ for approximately $6 \mathrm{~h}$ daily for 4 days (Group I), 5 days (Group II) and 7 days (Group III). Following the daily heat treatment the temperature in the chamber was allowed to fall slowly to the ambient temperature of the piggery (approximately 8 h). Heat treatment was carried out in a climate chamber which held 2 boars in individual metal crates. The boars were provided with water and remained in the chamber for the duration of the treatment period, except for semen collection. The temperature of the chamber was raised by 3 thermostatically controlled fan heaters. Temperatures and relative humidity within the chamber were recorded continuously on a hydrothermograph. The rectal and scrotal skin temperatures of the boars were recorded before daily treatment began, and every $2 \mathrm{~h}$ during heating, using an electric thermometer with 2 small thermistors, one placed in the rectum and one on the posterior surface of the scrotum between the 2 testes.

Statistical analysis. An analysis of variance was used to compare the mean weekly values of each semen parameter before, during and after treatment, for individual boars and for the 3 treatment groups.

The correlation coefficient, $r$, was estimated for each of the main morphological abnormalities in relation to rectal and scrotal skin temperatures and duration of exposure to elevated temperatures.

\section{Results}

The mean $( \pm$ s.d.) temperatures in the chamber during treatment ranged from $33.4 \pm 3 \cdot 1$ to $37.7 \pm 2{ }^{\circ} \mathrm{C}$; on occasions temperatures reached $40.0^{\circ} \mathrm{C}$ for short periods. The relative humidity was more difficult to control and fell from $80 \%$ at the beginning of treatment to about $40 \%$ as the chamber temperature rose.

Considerable variation was seen among boars in their reaction to the peak temperatures, 
especially during the first day of exposure (Table 1). In 3 of the boars, rectal temperatures of between 41 and $42^{\circ} \mathrm{C}$ were recorded, but in most, the temperature was between 38 and $39.5^{\circ} \mathrm{C}$ during treatment. Scrotal skin temperatures varied greatly among individual boars, ranging from 35 to $40^{\circ} \mathrm{C}$. Most boars suffered heat stress when rectal temperatures approached $40^{\circ} \mathrm{C}$, characterized by an increased respiratory rate, excessive drinking and restlessness. All boars appeared to adapt to the treatment as signs of heat stress were not as marked after the first 2 exposures. The treatments did not affect libido as boars retained a keen interest in the dummy sow, during and following the days of heat exposure.

Table 1. Mean \pm s.e.m. maximum temperatures achieved during the heating of the boars (4/group)

\begin{tabular}{lccc}
\hline $\begin{array}{c}\text { Temperature } \\
\left({ }^{\circ} \mathrm{C}\right)\end{array}$ & $\begin{array}{c}\text { Group I } \\
(24 \mathrm{~h})\end{array}$ & $\begin{array}{c}\text { Group II } \\
(32 \mathrm{~h})\end{array}$ & \multicolumn{1}{c}{$\begin{array}{c}\text { Group III } \\
(43 \mathrm{~h})\end{array}$} \\
\hline Ambient & $36.2 \pm 0.9$ & $35.3 \pm 0.6$ & $35.6 \pm 0.2$ \\
$\begin{array}{l}\text { Rectal } \\
\quad \text { Maximum }\end{array}$ & $39.8 \pm 0.2$ & $39.0 \pm 0.2$ & $39.4 \pm 0.7$ \\
$\quad$ Increase & $1.67 \pm 0.2$ & $1.17 \pm 0.1$ & $1.37 \pm 0.2$ \\
$\begin{array}{l}\text { Scrotal skin } \\
\text { Maximum }\end{array}$ & $36.7 \pm 0.3$ & $36.3 \pm 0.3$ & $37.0 \pm 0.2$ \\
$\quad$ Increase & $4.2 \pm 0.3$ & $4.6 \pm 0.1$ & $4.3 \pm 0.7$ \\
\hline
\end{tabular}

A significant decrease $(P<0.01)$ in seminal fluid volume was seen in 1 boar only during Weeks 3-6 after treatment. However, the mean fluid and gel volumes for the 3 treatment groups were not altered significantly by the treatments for any of the post-treatment periods. Sperm concentrations decreased significantly $(P<0.05)$ in 3 boars in Group II and in 1 boar in Group III. The total sperm number decreased significantly $(P<0.05)$ in 3 boars in Group I, 3 boars in Group II and in 1 boar in Group III. Daily sperm output declined in 5 of the 12 boars. Nevertheless, mean estimates of sperm concentration, total sperm number per ejaculate and daily sperm output did not differ significantly for any of the treatment groups. There were no differences between the groups for any of the characters measured and the results are presented as a mean for the 12 boars (Table 2).

Table 2. The semen characteristics (mean \pm s.e.m.) for 12 boars before and after exposure to elevated ambient temperatures

\begin{tabular}{|c|c|c|c|c|c|c|c|c|c|}
\hline & \multicolumn{9}{|c|}{ Weeks } \\
\hline & -1 & 0 & 1 & 2 & 3 & 4 & 5 & 6 & 7 \\
\hline Fluid vol. (ml) & $\begin{array}{r}208 \cdot 0 \\
\pm 12 \cdot 2\end{array}$ & $\begin{array}{l}208 \cdot 5 \\
\pm 16 \cdot 0\end{array}$ & $\begin{array}{l}216.8 \\
\pm 17.6\end{array}$ & $\begin{array}{r}198.5 \\
\pm 14.2\end{array}$ & $\begin{array}{l}200 \cdot 1 \\
\pm 14.6\end{array}$ & $\begin{array}{l}196 \cdot 3 \\
\pm 12 \cdot 6\end{array}$ & $\begin{array}{r}197.9 \\
\pm 10.2\end{array}$ & $\begin{array}{r}199.6 \\
\pm 12.4\end{array}$ & $\begin{array}{r}196 \cdot 1 \\
\pm 12.5\end{array}$ \\
\hline Gel vol. (ml) & $\begin{array}{r}110 \cdot 1 \\
\pm 10.5\end{array}$ & $\begin{array}{l}131 \cdot 1 \\
\pm 9 \cdot 1\end{array}$ & $\begin{array}{l}120.7 \\
\pm 8.6\end{array}$ & $\begin{array}{r}107 \cdot 8 \\
\pm 10.3\end{array}$ & $\begin{array}{l}106 \cdot 3 \\
\pm 7.7\end{array}$ & $\begin{array}{l}109.9 \\
\pm 8.7\end{array}$ & $\begin{array}{r}93.9 \\
+6.7\end{array}$ & $\begin{array}{c}98.5 \\
+7.8\end{array}$ & $\begin{array}{r}103.8 \\
\pm 8.6\end{array}$ \\
\hline $\begin{array}{l}\text { Sperm conc. } \\
\qquad\left(\times 10^{6} / \mathrm{ml}\right)\end{array}$ & $\begin{array}{l}139.1 \\
\pm 18.6\end{array}$ & $\begin{array}{r}117.5 \\
\pm 10.9\end{array}$ & $\begin{array}{l}102.7 \\
\pm 8.8\end{array}$ & $\begin{array}{l}107.3 \\
\pm 9.9\end{array}$ & $\begin{array}{r}109 \cdot 1 \\
\pm 10.2\end{array}$ & $\begin{array}{r}99.2 \\
\pm 9.1\end{array}$ & $\begin{array}{c}86.8 \\
\pm 8.4\end{array}$ & $\begin{array}{c}94.2 \\
\pm 8.8\end{array}$ & $\begin{array}{l}106 \cdot 5 \\
\pm 8 \cdot 2\end{array}$ \\
\hline $\begin{array}{l}\text { Total sperm no. } \\
\left(\times 10^{9} / \mathrm{ml}\right)\end{array}$ & $\begin{array}{r}26.4 \\
\pm 2.9\end{array}$ & $\begin{array}{r}21 \cdot 5 \\
\pm 1.4\end{array}$ & $\begin{array}{c}20.8 \\
\pm 1.7\end{array}$ & $\begin{aligned} & 20.5 \\
\pm & 1.9\end{aligned}$ & $\begin{aligned} & 21.8 \\
+ & 2.4\end{aligned}$ & $\begin{array}{r}19.9 \\
+2.2\end{array}$ & $\begin{array}{c}18.6 \\
+2.2\end{array}$ & $\begin{array}{r}18.5 \\
\pm 2.0\end{array}$ & $\begin{array}{r}20.9 \\
\pm 2.0\end{array}$ \\
\hline $\begin{array}{l}\text { Daily sperm output } \\
\left(\times 10^{9} / \mathrm{ml}\right)\end{array}$ & $13.4^{*}$ & & 7.9 & & 9.1 & & $8 \cdot 2$ & & 8.4 \\
\hline
\end{tabular}

* Calculated from 6 collections over 14 days.

The percentage of motile spermatozoa fell to $<80 \%$ in only 2 of the boars: one (in Group I) had $<50 \%$ motile spermatozoa during Week 4 and the other (in Group III) had $<30 \%$ during Weeks 3, 4 and 5 after treatment. The most common sperm abnormalities were narrow heads, 


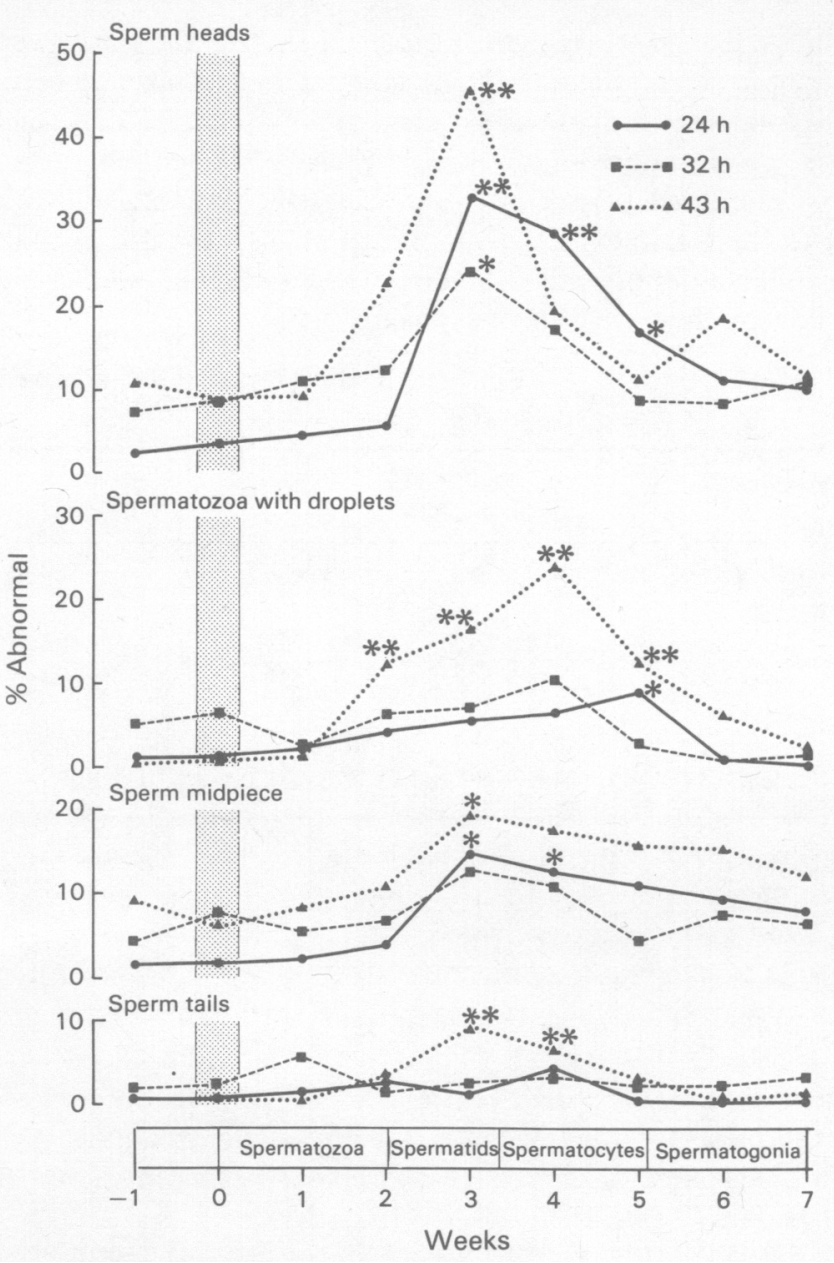

Text-fig 1. Sperm abnormalities seen in the ejaculates of boars subjected to elevated ambient temperatures (stippled column) for different times, plotted as a weekly mean percentage before, during, and for 7 weeks after treatment. The spermatogenic cycle of the boar is also presented to suggest the possible origin of the sperm abnormalities. Values significantly different from pretreatment mean: ${ }^{*} P<0.05,{ }^{* *} P<0.01$.

damaged acrosomes and abaxial midpieces (Text-fig. 1). There was a great variation among individuals, but only 1 boar did not show a significant increase in the percentage of spermatozoa with head abnormalities following heat treatment. The greatest increases occurred towards the end of Week 2 and reached a peak during Week 3 with a return to normal in the majority of boars by Week 7. Midpiece abnormalities increased in all but 1 boar during Weeks 3-6. The proportion of spermatozoa with abnormal tails increased significantly in 4 boars between Weeks 3 and 5 . In 1 boar a significant increase was found during Week 1 .

The percentage of spermatozoa with cytoplasmic droplets increased significantly in 2 boars, both in Group I, during Weeks 4 and 5 and in 2 boars in Group III during Weeks 2-5.

The percentage of spermatozoa with abnormal heads was correlated $(P<0.05)$ with rectal and scrotal temperature and with increase in rectal temperature while the percentage of tail abnormalities was correlated with rectal temperature and the increase in scrotal temperature. Midpiece abnormalities and percentage of cytoplasmic droplets showed no significant correlation with any of the temperature parameters (Table 3). 
Table 3. Correlations between sperm abnormalities and duration of exposure to heat, rectal temperature and scrotal skin temperature in boars

\begin{tabular}{llccc}
\hline & \multicolumn{4}{c}{ Sperm abnormalities } \\
\cline { 2 - 5 } & Head & Midpiece & Tail & Droplet \\
\hline Exposure time (h) & 0.20 & 0.49 & 0.46 & 0.52 \\
Rectal temp. (max. $\left.{ }^{\circ} \mathrm{C}\right)$ & $0.66^{*}$ & 0.21 & $0.63^{*}$ & 0.53 \\
Increase in rectal temp. $\left({ }^{\circ} \mathrm{C}\right)$ & $0.66^{*}$ & 0.36 & 0.52 & 0.39 \\
Scrotal temp. $\left(\max .{ }^{\circ} \mathrm{C}\right)$ & $0.67^{*}$ & 0.46 & 0.55 & 0.49 \\
Increase in scrotal temp. $\left({ }^{\circ} \mathrm{C}\right)$ & 0.34 & 0.20 & $0.67^{*}$ & 0.56 \\
\hline
\end{tabular}

* $P<0.05 ;$ d.f. $=10$.

\section{Discussion}

The temperatures and humidities applied in this experiment are comparable to environmental conditions experienced in some pig units in subtropical and tropical regions of Australia. The simulation of diurnal temperature variation more closely resembled field conditions than did similar experiments reported by McNitt \& First (1970), Christenson et al. (1972) and Wettemann et al. (1976). Although the treatment resulted in changes in the quality of semen in every boar, there was great variation among boars, ranging from very mild changes to the production of semen of very poor quality for several weeks. Gel volumes were not affected, and only 1 boar had a significant decline in fluid volume. McNitt \& First (1970) and Wettemann et al. (1976) were unable to demonstrate a significant decrease in semen volume or gel volume in their studies, and although Christenson et al. (1972) appeared to have produced a decline in semen volume in a group of boars subjected to $33^{\circ} \mathrm{C}$ for $72 \mathrm{~h}$ their results were not examined statistically. Christenson et al. (1972) also found that sperm concentration and total numbers of spermatozoa per ejaculate decreased 2 weeks after treatment, but this only occurred in some boars in the present study: in 2 of the boars the decline immediately followed the heat treatment and this precludes a direct effect on spermatogenesis.

Daily sperm output is considered to be a reliable indicator of sperm production of the testis (Amann, 1970) and as it was not significantly changed in any of the three groups it was concluded that sperm production by the testis was not generally affected by the heat treatment although some individual boars were affected.

The highest rectal temperatures were recorded in 2 boars in which poor sperm motility coincided with an increase in abnormal tails, 3-4 weeks after treatment. Similar findings were reported by McNitt \& First (1970) and Wettemann et al. (1976).

Mazzarri et al. (1968) applied heat directly to the scrotum of boars and found decreased sperm motility towards the end of the 2nd week after treatment. Epididymal transit time in the boar has been estimated to last for 9-14 days (Singh, 1962; Swierstra, 1968), and epididymal function in the boar is probably therefore not easily affected by elevated temperatures. Howarth (1969) and Braden \& Mattner (1970) also found for rams that spermatozoa in the epididymis were more resistant to high temperatures than were cells in the testis.

The most obvious effect of heat was on sperm morphology. Similar findings were reported by McNitt \& First (1970), Christenson et al. (1972) and Wettemann et al. (1976). Comparison of the first interval between treatment and the appearance of morphological abnormalities with the spermatogenic cycle of the boar, as described by Swierstra (1968), showed that the spermatogenic cells most affected by heat were the elongated and round spermatids and the late spermatocytes. This is in agreement with studies in the ram (Samisoni \& Blackshaw, 1971; Williamson, 1974) and rat (Chowdhury \& Steinberger, 1963, 1970; Collins \& Lacy, 1969; Blackshaw, Hamilton \& Massey, 1973). The significant increase in cytoplasmic droplets 3-5 
weeks after treatment may be an effect on primary spermatocytes resulting in interference with droplet release in the epididymis or the long-term effect of elevated temperatures on the epididymis (Singleton, 1974). Acrosomal damage was similar to that described by Purcel, Johnson \& Rampacek (1972) resulting from cold shock. Rathore (1970) and Cameron (1971) also reported acrosomal damage in ram spermatozoa due to heat stress. In general the severity of semen changes was directly related to the duration of exposure to heat, although in some boars the incidence of abnormal sperm heads and tails was related to rectal temperatures, regardless of the total exposure time. McNitt, Tanner \& First (1972) suggested that rectal temperatures directly influenced testicular temperature in the boar. Short periods of elevated ambient temperatures affected the quality but not always the quantity of semen production of boars with the effect most apparent 3-5 weeks later. The extent of damage may be directly related to the ability of the animal to adapt to heat stress and minimize the rise in body and scrotal temperature and, therefore, maintain normal testicular function. Egbunike \& Elemo (1978) have shown that European boars can adapt to a tropical climate and maintain normal semen production rates. Similarly, in this study boars reared at temperatures of $30^{\circ} \mathrm{C}$ required acute exposure to temperatures of $35^{\circ} \mathrm{C}$ or more before spermatogenesis was adversely affected.

We thank Mr S. Sturgess for his assistance with the collection of the boar semen; Mrs A. J. Vickers (Department of Animal Production Semen Laboratory) for examination of the semen smears; and Mr J. McVeigh for care and management of the animals.

\section{References}

Amann, R.P. (1970) Sperm production rates, In The Testis, vol. 1, Chapter 7, pp. 435-480. Eds A. D. Johnson, W. R. Gomes \& N. L. VanDemark. Academic Press, New York.

Anderson, J. (1945) Seasonal variation in the reproductive capacity of the bull. J. agric. Sci., Camb. 35, 184-196.

Blackshaw, A.W., Hamilton, D. \& Massey, P.F. (1973) Effect of scrotal heating on testicular enzymes and spermatogenesis in the rat. Aust. J. biol. Sci. 26, 1395-1407.

Braden, A.W.H. \& Mattner, P.E. (1970) The effect of scrotal heating in the ram on semen characteristics, fecundity and embryonic mortality. Aust. J. agric. Res. 21, 509-518.

Cameron, R.D.A. (1971) A study of spermatozoa in the ram. M.V.Sc. thesis, University of Queensland, Brisbane.

Chowdhury, A.K. \& Steinberger, E. (1963) Selective damage induced by heat to the testicular germinal epithelium of rats. Anat. Rec. 145, 217.

Chowdhury, A.K. \& Steinberger, E. (1970) Early changes in germinal epithelium of rat testis following exposure to heat. J. Reprod. Fert. 22, 205-212.

Christenson, R.K., Teague, H.S., Grifo Jr., A.P. \& Roller, W.L. (1972) The effect of high environmental temperature on the boar. Ohio Swine Research and Information Report: Research Summary 61, pp. 19-23. Ohio Agric Res. Dev. Center, Wooster.

Collins, P.M. \& Lacy, D. (1969) Studies on the structure and function of the mammalian testis. II. Cytological and histochemical observations on the testis of the rat after a single exposure to heat applied for different lengths of time. Proc. $R$. Soc. B 172, 17-38.
Dutt, R.H. \& Hamm, P.T. (1957) Effect of exposure to high environmental temperatures and shearing on semen production of rams in winter. J. Anim. Sci. 16, 328-334.

Egbunike, G.N. \& Elemo, A.O. (1978) Testicular and epididymal sperm reserves of crossbred European boars raised and maintained in the humid tropics. $J$. Reprod. Fert. 54, 245-248.

Gunn, R.M.C., Sanders, R.N. \& Granger, W. (1942) Studies in fertility in sheep. II. Seminal changes affecting fertility in rams. Australia, Commonwealth, Council Sci. Ind. Res., Bull. 148.

Howarth, B., Jr (1969) Fertility in the ram following exposure to elevated ambient temperature and humidity. J. Reprod. Fert. 19, 179-183.

Kennelly, J.J. \& Foote, R.H. (1964) Sampling boar testis to study spermatogenesis quantitatively and to predict sperm production. J. Anim. Sci. 23, 160167.

Lagerlöf, N. (1936) Sterility in bulls. Vet. Rec. 48, 1159-1173.

Lawrence, J.A., Turman, E.J., Rich, T., Sharp, A. \& Hillies, J.C. (1970) A study of seasonal changes in boar semen. Bull. Okla. agric. Exp. Stn MP-84, 77-83.

McKenzie, F.F. \& Berliner, V. (1937) The reproductive capacity of the ram. Res. Bull. Mo. agric. Exp. Stn No. 265.

McNitt, J.I. \& First, N.L. (1970) Effects of 72-hour heat stress on semen quality in boars. Int. J. Biometeor. 14, 373-380.

McNitt, J.I., Tanner, C.B. \& First, N.L. (1972) Thermoregulation in the scrotal system of the boar. I. Temperature distribution. J. Anim. Sci. 34, 112-116. 
Mazzarri, G., du Mesnil du Buisson, F. \& Ortavant, R. (1968) Action of temperature on spermatogenesis, sperm production and fertility of the boar. Proc. 6th Int. Congr. Anim. Reprod. \& A.I., Paris, Vol. 1, pp. 305-308.

Phillips, R.W., Knapp, B., Heemstra, L.C. \& Eaton, O.N. (1945) Seasonal variation in the semen of bulls. Am.J. vet. Res. 4, 115.

Purcel, V.G., Johnson, L.A. \& Rampacek, G.B. (1972) Acrosome morphology of boar spermatozoa incubated before cold shock. J. Anim. Sci. 34, 278-283.

Rathore, A.K. (1970) Acrosomal abnormalities in ram spermatozoa due to heat stress. Br. vet. J. 126, $440-443$.

Samisoni, J.I. Blackshaw, A.W. (1971) Early changes in the histology and cytochemistry of the heated ram testis. J. Reprod. Fert. 24, 150-151.

Signoret, J.P. \& du Mesnil du Buisson, F. (1968) Influence des conditions d'habitat du verrat sur la fecondance du sperme. Proc. 6th Int. Congr. Anim. Reprod.\& A.I., Paris, Vol. 1, p. 317.

Singh, G. (1962) Durée de passage dans l'epididyme des spermatozoides de verrat marqués au p-32. Annls Biol. anim. Biochim. Biophys. 2, 43-46.
Singleton, E.F. (1974) The effect of heat on reproductive function in the bull. Ph.D. thesis, University of Queensland, Brisbane.

Stork, M.G. (1979) Seasonal reproductive inefficiency in large pig breeding units in Britain. Vet. Rec. 104, 49-52.

Swierstra, E.E. (1968) Cytology and duration of the cycle of the seminiferous epithelium of the boar; duration of spermatozoan transit through the epididymis. Anat. Rec. 161, 171-186.

Thibault, C.M., Courot. M., Martinet, L., Mauleon P., du Mesnil du Buisson, F., Ortavant, R., Pelletier, J. \& Signoret, J.P. (1966) Regulation of breeding season and estrous cycle by light and external stimuli in some mammals. J. Anim. Sci. 25 (Suppl.), 119-139.

Wettemann, R.P., Wells, M.E., Omtvedt, I.T., Pope, C.E. \& Turman, E.J. (1976) Influence of elevated ambient temperature on reproductive performance of boars. $J$. Anim. Sci. 42, 664-669.

Williamson, P. (1974) The effect of elevated temperature on acrosome formation in the ram. J. Reprod. Fert. $36,440-441$.

Received 15 October 1979 